\title{
G

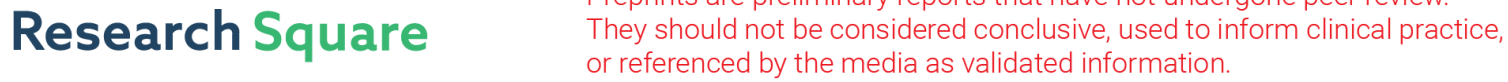 \\ COVID-19 outbreak in Brazil: Adherence to national preventive measures and impact on people's lives
}

\section{Edlaine Faria de Moura Villela ( $\nabla$ edlaine@ufg.br)}

School of Medicine, Health Sciences Unit, Federal University of Jataí, Brazil https://orcid.org/00000002-7043-2007

\section{Rossana Verónica Mendoza Lopez}

Center for Translational Research in Oncology, Institute of Cancer of São Paulo State, Brazil

\section{Ana Paula Sayuri Sato}

Department of Epidemiology, School of Public Health, University of São Paulo, Brazil

\section{Fábio Morato de Oliveira}

School of Medicine, Health Sciences Unit, Federal University of Jataí, Brazil

\section{Eliseu Alves Waldman}

Department of Epidemiology, School of Public Health, University of São Paulo, Brazil

\section{Rafael Van den Bergh}

Global Health Institute, University of Antwerp, Antwerp, Belgium

Joseph Nelson Siewe Fodjo

Global Health Institute, University of Antwerp, Antwerp, Belgium

\section{Robert Colebunders}

Global Health Institute, University of Antwerp, Antwerp, Belgium

\section{Research Article}

Keywords: Prevention and control, Pandemics, Population health management, Public health surveillance, COVID-19

Posted Date: July 12th, 2020

DOI: https://doi.org/10.21203/rs.3.rs-40186/v1

License: (c) (i) This work is licensed under a Creative Commons Attribution 4.0 International License. Read Full License 


\section{Abstract}

Background: The first case of COVID-19 infection was diagnosed in Brazil $26^{\text {th }}$ February 2020. By March $16^{\text {th }}$, physical distancing and confinement measures were implemented by the Brazilian government. Little is known about how these measures were followed up by the Brazilian people and their impact on daily routine.

Methods: In early April 2020, using an online platform, we organized an online survey among adults living in Brazil about their COVID-19 preventive behavior.

Results: Data from 23.896 respondents were analyzed (mean age: 47.4 years). Due to COVID-19 restrictions, half (51.1\%) of the professionals reported working from home. Regular handwashing was practiced by $98.7 \%$ of participants; $92.6 \%$ reported adhering to the $1.5-2 \mathrm{~m}$ physical distancing rule, but only $45.5 \%$ wore a face mask when going outside. While $29.3 \%$ of respondents found it relatively easy to stay at home, indoor confinement was extremely difficult for $7.9 \%$ of participants. Moreover, $11 \%$ of participants were extremely worried about their health during the COVID-19 epidemic.Younger people, male, persons living in a rural area/village or popular neighbourhoods, students and workers reported less preventive behaviour.

Conclusion: Restrictive measures markedly affected the daily and professional routines of Brazilians. Participants showed a satisfactory level of adherence to national COVID-19 prevention guidelines. Qualitative and follow-up studies are needed to monitor the impact of COVID-19 in the Brazilian society.

\section{Background}

On December 31st 2019, the World Health Organization (WHO) received a notification of an unknown viral pneumonia outbreak in the Hubei Province of China. This outbreak was later found to be caused by the Severe Acute Respiratory Syndrome Coronavirus $2[1,2]$. The disease, now called Coronavirus Disease 2019 (COVID-19), has quickly spread to most countries of the world, affecting almost 5 million individuals and causing more than 320,000 deaths. Until May 22, 492,124 cases were registered in the South America, with $55,3 \%$ being in Brazil [3].

COVID-19 is primarily transmitted by respiratory droplets with a similar incubation time and development time as the previously known Severe Acute Respiratory Syndrome Coronavirus (SARSCoV) [1,4]. The rapid international spread of COVID-19 pressured the WHO to declare the COVID-19 epidemic as a public health emergency of international importance in late January 2020. Such a decision is taken when an event with major public health implications crosses the borders of the country initially affected, demanding immediate international action [5]. Although vaccines and antivirals are not yet available, various public health strategies to contain the infection have been implemented around the world. These strategies commonly consist of enforced or semi-enforced "lockdowns" and closure of national and/or intra-national borders, as well as promotion of respiratory hygiene (masking, coughing/sneezing etiquette) and hand hygiene. The package of containment measures for COVID-19 around the world 
probably represents the largest global public health intervention in human history, though the societal and individual impact of these measures is not yet well-understood.

The population-level adherence to such measures may determine to a considerable extent the national magnitude and duration of the COVID-19 pandemic [6,7]. However, little is known on population-level adherence to the various containment measures implemented worldwide, with most studies focusing on adherence to hygiene measures among healthcare workers $[8,9,10]$. In-depth documentation of adherence to containment measures is nonetheless essential, on the one hand to feed into initiatives attempting to model outbreaks $[6,11]$, and on the other hand to adapt and target health promotion messages to subpopulations that may be struggling to adhere to specific measures [12], such as specific age groups.

In Brazil, the first case of COVID-19, reported by the Ministry of Health (MOH) on February 26th, was a 61-year-old man who had traveled to Italy between February 9 and 21 of 2020. Two tests were positive for COVID-19 infection. Since then, the number of infected persons in Brazil has increased dramatically [13]. Physical distancing and confinement measures were implemented by the Brazilian government after COVID-19 was declared a pandemic on March 16th [5]. Events expected to attract large numbers of people were cancelled, universities and schools were closed, and only services considered essential to the population remained functional, such as markets, pharmacies and bakeries. However, traveling between Brazilian states remained possible. To document how the containment measures affected the lives of the Brazilian people, and to understand which containment measures were best adhered to by which strata of the population, we conducted an online survey on the adherence of the Brazilian people to individual public health measures and impact of the COVID-19 outbreak on people's lives. A particular emphasis was placed on age as a stratifying factor, considering the clear association of COVID-19 severity with age, and the general need for adapting health messaging to specific age groups.

\section{Methods}

\section{Study design}

An online questionnaire survey was organized in Brazil between April 3 to April 9. At the time of the survey Brazil counted 9,056 confirmed COVID-19 cases, 1769 hospitalizations and 359 deaths. People were invited via social media to anonymously respond to a secure web-based online questionnaire (www.icpcovid.com) and to disseminate the survey link further in their network.

The questionnaire consisted of 60 questions about individual preventive measures and daily living practices (Additional file 1). We used Likert scores for questions concerning health risk perception and the level of difficulty to observe the confinement instructions.

\section{Data analysis}


Statistical analysis was performed using IBM SPSS version 25 for Windows. Containment measures were grouped into three main categories: hand hygiene, respiratory hygiene, and physical distancing/isolation. A composite adherence score was generated for each of these categories using specific questions from the survey, with empirical weights (Table 1). Subsequently an overall adherence score was generated by combining the sub- scores in a 1:1:1 ratio.

Table 1. Composite adherence score to COVID-19 preventive measures

\begin{tabular}{lc}
\hline Preventive measures & $\begin{array}{c}\text { Composite adherence } \\
\text { score }\end{array}$ \\
\hline $\begin{array}{l}\text { Hand hygiene } \\
\text { Wash hands regularly with water and soap OR with alcohol gel }\end{array}$ & 1 \\
\hline Avoid touching face & 0.5 \\
\hline Disinfect cell phone & 0.5 \\
\hline Respiratory hygiene & Divide total score by 2 \\
\hline Wear a face mask when leaving home & 1 \\
\hline Cover mouth/nose when leaving home & 1 \\
\hline Wash hands after coughing/sneezing & Divide total score by 3 \\
\hline $\begin{array}{l}\text { Physical distancing/isolation } \\
\text { Follow rule of staying 1.5-2m from other people }\end{array}$ & 1 \\
\hline Measure temperature twice a week & 0.5 \\
Stay home when experiencing flu-like symptoms (among people who had flu-like & 1
\end{tabular}

Divide total score by 2.5

Overall composite score across all measures (1:1:1 ratio of specific score

Descriptive statistics were presented using means with standard deviation (SD) for continuous outcomes, and percentages (\%) for categorical variables. We used Pearson's chi-square test to investigate associations between two categorical variables. The Wilcoxon test was used to compare the number of days of work per week before and after the epidemic.

We used a linear regression model to analyze factors associated with adherence to national prevention restrictive measures. Variables with $p<0.10$ in bivariate analysis were included in the adjusted model with a backward stepwise process. The dependent variable was the overall composite score across all adherence measures described in Table 1. Covariates included: age, gender, state and area of residence, education, marital status, living alone, profession, working in the health sector and comorbidities. The significance level adopted was $5 \%$ for all hypothesis tests.

\section{Results}

\section{Characteristics of respondents}


A total of 25,266 persons participated in the survey. After excluding respondents younger than 18 years ( $\mathrm{n}$ $=163$ ) and people with inconsistent responses $(1,207), 23,896$ respondents $(94.6 \%)$ were included for analysis. Participants were from all parts of the country. The median age of participants was 48.0 years (IQR 37.0-58.0 years); 71.8\% were women (Table 2). 7020 (29.4\%) reported a chronic underlying disease such as diabetes, cancer, HIV infection or tuberculosis and 2177 were smokers of cigarettes.

Table 2. Characteristics of study participants in an online survey on COVID-19, Brazil, April 2020

\begin{tabular}{|c|c|c|c|}
\hline Characteristics & $\mathrm{N}=23896$ & & \\
\hline Continuous variables & & \multirow[b]{2}{*}{47.4} & \\
\hline \multirow[t]{5}{*}{ Age in years } & Mean (SD) & & \\
\hline & & $(13.8)$ & \\
\hline & Median (Q1-Q3) & \multirow{2}{*}{$\begin{array}{c}48 \\
\end{array}$} & \\
\hline & & & \\
\hline & Range & $18-89$ & \\
\hline Categorical variables & & $\mathrm{N}$ & $\%$ \\
\hline \multirow[t]{3}{*}{ Age group } & 18-25 years & 1652 & 6.9 \\
\hline & 26-65 years & 20109 & 84.2 \\
\hline & $>65$ years & 2135 & 8.9 \\
\hline \multirow[t]{2}{*}{ Gender } & Male & 6741 & 28.2 \\
\hline & Female & 17155 & 71.8 \\
\hline \multirow[t]{5}{*}{ Brazilian region of residence } & North & 299 & 1.4 \\
\hline & Northeast & 2315 & 10.5 \\
\hline & Central-West & 2489 & 11.3 \\
\hline & Southeast & 13447 & 61.2 \\
\hline & South & 3428 & 15.6 \\
\hline \multirow[t]{2}{*}{ Nationality } & Brazilian & 23746 & 99.4 \\
\hline & Foreign & 150 & 0.6 \\
\hline \multirow[t]{2}{*}{ Highest educational level } & I didn't complete elementary school & 1 & 0.0 \\
\hline & Primary School & 99 & 0.4 \\
\hline
\end{tabular}

\begin{tabular}{llcc} 
& Secondary School & 2437 & 10.2 \\
\cline { 2 - 4 } & University Undergraduate degree holder & 7604 & 31.8 \\
\cline { 2 - 4 } Marital status & University Postgraduate degree holder & 13755 & 57.6 \\
\hline & Single & 5876 & 24.6 \\
\hline & Legally married & 12167 & 50.9 \\
\hline & Cohabitation & 2556 & 10.7 \\
\hline \multirow{2}{*}{ Residential setting } & Divorced & 2713 & 11.4 \\
\hline & Widow/widower & 584 & 2.4 \\
\hline & Downtown area & 13046 & 54.6 \\
\hline & Suburb area & 4531 & 19.0 \\
\hline & Rural area/village & 631 & 2.6 \\
\hline & Popular neighborhoods & 5688 & 23.8
\end{tabular}

\section{Professional impact of COVID-19 restrictive measures}


At the time of the survey, $44.6 \%$ of professionals were working from home. For those who were not working from home, $66.1 \%$ were not able to do so because of the type of job, $9.1 \%$ were not allowed by their employer, $5 \%$ had to leave the house to make money to support the family, and $1.3 \%$ left the home because they considered this to be without a risk (Table 3). Due to COVID-19 restrictions, participants reported going to work less often (mean number of days of work per week: 0.8 ) compared to the period before the epidemic (mean number of days of work per week: 3.2; p-value<0.001; Wilcoxon test).

Table 3. Professional impact of COVID-19 restrictions reported among participants of an online survey on COVID-19, Brazil, April 2020

\begin{tabular}{|c|c|c|c|}
\hline Characteristics & Description & $\mathrm{n}$ & $\%$ \\
\hline \multirow[t]{6}{*}{ Profession } & Unemployed & 938 & 3.9 \\
\hline & Student & 1551 & 6.5 \\
\hline & Self-employed & 5235 & 21.9 \\
\hline & Work for the government (federal, state, municipal) & 7028 & 29.4 \\
\hline & Work for a person, institution or company & 5200 & 21.8 \\
\hline & Other & 3944 & 16.5 \\
\hline Healthcare worker & Yes & 7293 & 30.5 \\
\hline $\begin{array}{l}\text { Current working } \\
\text { conditions }\end{array}$ & Work from home & 9544 & 44.6 \\
\hline \multirow[t]{4}{*}{$(n=21407$ workers $)$} & Work in an open space (market, shop, roadside, etc) & 1452 & 6.8 \\
\hline & $\begin{array}{l}\text { Work in a closed indoor space with several people (office, } \\
\text { etc.) }\end{array}$ & 5614 & 26.2 \\
\hline & Work in a closed indoor space alone (office, etc.) & 1833 & 8.6 \\
\hline & Not informed & 2964 & 13.8 \\
\hline Reasons not to work from & It is not possible with my job & 3918 & 66.1 \\
\hline \multirow[t]{4}{*}{ home ( $n=5931$ workers $)$} & It is possible, but is not allowed by my employer & 540 & 9.1 \\
\hline & I don't think there is any risk to go out & 76 & 1.3 \\
\hline & $\begin{array}{l}\text { I have to leave the house to make money to support my family } \\
\text { Other }\end{array}$ & 298 & 5.0 \\
\hline & & 1099 & 18.5 \\
\hline
\end{tabular}

\section{Impact on personal life}

While $29.3 \%$ of respondents found it relatively easy to stay at home, indoor confinement was extremely difficult for $7.9 \%$ of participants. When queried on their concerns about COVID-19 consequences, respondents were more concerned about the health of their loved ones (29.9\% very concerned and $22.2 \%$ concerned) than their own health (11.0\% very concerned and $13.9 \%$ concerned) (Figure 1$)$.

\section{Adherence to the national COVID-19 restrictions}

Regression analysis was carried out to identify factors associated with higher overall adherence. Older age, being female, living alone, being self-employed, living in the Northeast region, having at least an undergraduate degree, being a health care worker, and having comorbidities were all independently associated with a higher overall score (Table 4). 
Table 4. Factors associated with adherence to national prevention restrictive measures among participants of an online survey on COVID-19, Brazil, April 2020

\begin{tabular}{|c|c|c|c|c|c|}
\hline Variable & Categories & p-value & B & Standard Error & CI 95\% \\
\hline \multirow[t]{3}{*}{ Age } & $\begin{array}{l}\text { Intercept } \\
18-25\end{array}$ & $<0,0001$ & 4,242 & 0,1452 & $3,957-4,526$ \\
\hline & $26-65$ & $<0,001$ & 0,389 & 0,0413 & $0,308-0,47$ \\
\hline & $>65$ & $<0,001$ & 0,533 & 0,0504 & $0,434-0,631$ \\
\hline \multirow[t]{2}{*}{ Gender } & Male & & & & \\
\hline & Female & $<0,001$ & 0,281 & 0,0172 & $0,247-0,315$ \\
\hline \multirow{5}{*}{$\begin{array}{l}\text { State of } \\
\text { residence }\end{array}$} & North & & & & \\
\hline & Northeast & 0,045 & 0,137 & 0,0685 & $0,003-0,272$ \\
\hline & Midwest & 0,144 & $-0,100$ & 0,0683 & $-0,234-0,034$ \\
\hline & Southeast & 0,608 & $-0,033$ & 0,0654 & $-0,162-0,095$ \\
\hline & South & 0,443 & $-0,052$ & 0,0674 & $-0,184-0,08$ \\
\hline \multirow[t]{4}{*}{ Education } & Primary School or less & & & & \\
\hline & Secondary School & 0,178 & 0,164 & 0,1220 & $-0,075-0,404$ \\
\hline & Undergraduate & 0,066 & 0,222 & 0,1206 & $-0,014-0,458$ \\
\hline & Postgraduate & 0,009 & 0,317 & 0,1206 & $0,081-0,554$ \\
\hline \multirow[t]{5}{*}{ Marital Status } & Single & & & & \\
\hline & Legally married & $<0,001$ & 0,092 & 0,0221 & $0,049-0,136$ \\
\hline & Cohabitation & 0,825 & 0,007 & 0,0295 & $-0,051-0,064$ \\
\hline & Divorced & $<0,001$ & 0,138 & 0,0285 & $0,082-0,194$ \\
\hline & Widow/widower & $<0,001$ & 0,231 & 0,0520 & $0,129-0,333$ \\
\hline \multirow{2}{*}{ Living alone } & No & & & & \\
\hline & Yes & 0,009 & 0,073 & 0,0282 & $0,018-0,129$ \\
\hline \multirow{5}{*}{$\begin{array}{l}\text { Area of } \\
\text { residence }\end{array}$} & Downtown area & & & & \\
\hline & Suburban area & 0,246 & $-0,024$ & 0,0203 & $-0,063-0,016$ \\
\hline & Rural area/village & $<0,001$ & $-0,220$ & 0,0469 & $-0,312--0,128$ \\
\hline & Popular & 0,019 & $-0,044$ & 0,0189 & $-0,081--0,007$ \\
\hline & neighborhoods & & & & \\
\hline \multirow[t]{8}{*}{ Profession } & Unemployed & & & & \\
\hline & Student & 0,049 & $-0,107$ & 0,0543 & $-0,213-0$ \\
\hline & Self-employed & 0,018 & 0,099 & 0,0416 & $0,017-0,18$ \\
\hline & Work for the & 0,790 & $-0,011$ & 0,0412 & $-0,092-0,07$ \\
\hline & $\begin{array}{l}\text { government (federal, } \\
\text { state, municipal) }\end{array}$ & & & & \\
\hline & $\begin{array}{l}\text { Work for a person, } \\
\text { institution or }\end{array}$ & 0,035 & $-0,087$ & 0,0414 & $-0,168--0,006$ \\
\hline & $\begin{array}{l}\text { institution or } \\
\text { company }\end{array}$ & & & & \\
\hline & None of the previous & $<0,001$ & 0,192 & 0,0433 & $0,108-0,277$ \\
\hline \multirow{2}{*}{$\begin{array}{l}\text { Health care } \\
\text { worker }\end{array}$} & No & & & & \\
\hline & Yes & $<0.001$ & 0,124 & 0,0175 & $0,09-0,158$ \\
\hline \multirow[t]{2}{*}{ Comorbidities } & Not that I know & & & & \\
\hline & Yes & $<0,001$ & 0,165 & 0,0169 & $0,132-0,198$ \\
\hline
\end{tabular}

Adherence scores for the specific measures were all significantly lower in the younger age group (18-25 years). Respiratory hygiene and physical distancing adherence scores

\section{Discussion}


Our study shows that, during the survey period, Brazilians were following the COVID-19 preventive measures relatively well. Hand hygiene measures were adhered to most, followed by physical distancing and respiratory hygiene. In all categories of measures, a clear age effect was observed, with younger individuals (18-25 years old) scoring lowest and people $>65$ years old showing the highest preventive adherence score. This effect was most pronounced for respiratory hygiene.

Overall, only $45.5 \%$ reported wearing a face mask when going out. This is much lower than in Asian countries, where most people wear face masks once the COVID-19 epidemic was introduced in their country $[14,15,16]$. This is however higher than in several European countries where initially wearing facemasks was initially advised, following WHO recommendations, only to be used in health care settings $[17,18,19]$. Checking one's temperature for the early detection of a COVID-19 infection at least twice a week was only practiced by $10.8 \%$ of the respondents. This may be a point of concern, as WHO reported that temperature screening was able to detect the majority of exported cases during the COVID19's expansion [20].

When assessing the profile of individuals with poor general adherence, men were less adherent compared to women, which mirrors findings from a Knowledge, Attitudes, and Practices study conducted in China (16). People living in rural areas and poor neighborhoods were also less adherent: in rural areas people may not perceive themselves at high risk of COVID-19, and therefore may not respect the national restriction measures and not practice individual hygiene measures [21]. Therefore, extra communication and health education may be needed to change the risk perception in rural areas and popular neighborhoods [22]. Brazilian students reported difficulties to stay home, which may be related to a need to travel to their original homes in periods when schools and universities were closed [23] or could be related to differing social habits among this population. Encouragingly, respondents with underlying diseases followed the preventive measures well, which is important considering their higher risk for more severe disease.

Taken together, these observations suggest that tailoring of the public health messages may be indicated. A reinforcement of specific messages, such as mask use and temperature taking, may be beneficial, and using delivery methods tailored to the specific age groups could allow higher uptake. Especially communication methods to the younger age group could benefit from such tailoring, and possibly approaches relying on social media and including influencers to spread public health messages could be considered [24]. Of note, the observation that most respondents' concern was higher for their loved ones than for themselves could be incorporated in such health messages; possibly by emphasizing how adhering to measures protects one's close environment.

In general, our results indicate that following an intensive COVID-19 prevention campaign [25] the Brazilians gradually became aware of the importance of adopting simple methods to prevent COVID-19 transmission. For only $7.9 \%$, of the interviewees, the incorporation of "new habits" was extremely difficult. Initially the $\mathrm{MOH}$ of Brazil expected a peak of COVID-19 infections during the second half of April. However, it did not happen. According to a new estimate from the $\mathrm{MOH}$, the peak is now expected by the 
end of May [26]. The satisfactory adherence to the preventive measures may have delayed the peak of the epidemic.

COVID-19 associated mortality is highest Brazil, in the North region (Amazonas, 178) and in two states in the Northeast (Ceará and Pernambuco) [27]. Our study showed that the Northeast region had less difficulty to adhere the restrictive measures. This difference between regions may have been influenced by the adoption of restrictive measures to varying degrees by the governors of the Brazilian states. Indeed, 11 states have decreed lockdown for at least one municipality in their state. Only the state of Amapá decreed a lockdown for all your municipalities.

Currently there is a lot of confusion about how to deal with the COVID-19 epidemic in Brazil. The president has minimized the actions of the $\mathrm{MOH}$, downplaying the importance of quarantine, and is defending vertical isolation to avoid financial collapse. Vertical isolation or shielding means, most people return back to normal life and people with underlying diseases, older adults and pregnant women continue to respect physical distance and reduce their social activities. Regarding this vulnerable group, $29.4 \%$ stated to have underlying diseases in our survey. This is a concern, as older age and the presence of (an) underlying health condition(s) are associated with increased COVID-19 related mortality $[28,29]$ On the other hand, Brazilian respondents with underlying diseases adhered better to the containment measures.

The lack of unified actions against COVID-19, by the federal government, led to the resignation of the health minister on April 16 [30,31]. From that moment on, there was a relaxation of quarantine measures, opening of part of the trade, and consequently less physical distancing. This increased the number of COVID-19 cases and associated deaths [28,31]. At the end of April, the COVID-19 death toll in Brazil had already exceeded that of China [3] (more than 5,000 deaths) and this scenario is getting worse, not reaching the flattening of the curve and overloading the Brazilian health system [32]. As of May 22th $2020,291,579$ cases had been confirmed in the country, causing 18,859 deaths [2,5]. Currently South America is the new epicenter of the pandemic and Brazil is the country most affected [3]. Our findings suggest a considerable initial willingness of the Brazilian people to follow the quarantine and other containment measures, and it remains to be investigated whether this willingness has been irrevocably subverted through the political stance against the public health measures, or whether it can still be harnessed to achieve better control of the national situation.

Our study had several limitations. The number of respondents was relatively small compared to the entire Brazilian population, and respondents were unevenly spread over the national territory. Indeed, only $2,6 \%$ of the participants reported residing in rural areas. In addition, $71,8 \%$ of the respondents were female, similar to other studies on COVID-19-related practices (16). Participants were more likely to be higher educated individuals living in cities and in the Southeast region. The latter may be explained by the fact that since the beginning of the pandemic, this region recorded the largest number of COVID-19 infections. Moreover, broadband internet quality is best in the Southeast region [33]. Our survey was also not able to reach vulnerable populations, such as the homeless, prisoners, older adults, migrants and 
people with mobility problems. Such populations may be at increased risk for COVID-19 infection and should be considered as priority key groups in the prevention and control of Covid-19 [23,34].

\section{Conclusion}

In conclusion, most participants in this survey correctly followed the COVID-19 prevention guidelines, although staying at home was difficult for specific groups, and younger age groups tended to adhere less to containment measures. Larger follow up surveys and in-depth qualitative studies about the preventive behavior of different groups in the Brazilian society are needed. The adherence to the COVID-19 preventive measures will need to be monitored closely as restrictive measures are being relaxed.

\section{List Of Abbreviations}

Coronavirus Disease 2019: COVID-19 Ministry of Health: $\mathrm{MOH}$

Standard deviation: SD

World Health Organization: WHO

\section{Declarations}

\section{Ethical Approval and consent to participate}

The study was conducted in accordance with the Declaration of Helsinki and the protocol was approved by the National Research Ethics Commission, Brazil (Protocol number: 30343820.9.0000.0008, dated April 01, 2020). The need for consent was waived by the National Research Ethics Commission, according to national regulations (Resolution Number 466, December 12, 2012).

Consent for publication

Not applicable

Availability of data and materials

The datasets used and/or analysed during the current study are available from the corresponding author on reasonable request.

Competing interests

The authors declare no conflict of interest.

Funding

Not applicable. 
EFMV and RC conceived the study, coordinated the analysis and wrote the first draft of the manuscript. RVML and APSS conducted the statistical analysis and contributed to the interpretation of data. FMO and EAW provided important contributions to the design of the work and revised it substantively. RVdB and JNSF provided analysis, editorial support and revised it. All authors critically reviewed and approved the submitted version (and any substantially modified version that involves the author's contribution to the study); All authors have agreed both to be personally accountable for the author's own contributions and to ensure that questions related to the accuracy or integrity of any part of the work, even ones in which the author was not personally involved, are appropriately investigated, resolved, and the resolution documented in the literature.

\section{Acknowledgements}

Special thanks to the Epidemiology and Health Services Observatory (EpiServ Team, Brazil) and to the Epidemiology and Public Health Research Group (EPICOL/CNPq, Brazil).

\section{References}

1. Zhu N, Zhang D, Wang W et al. A novel coronavirus from patients with pneumonia in China, 2019.N Engl J Med 2020; 382:727-3.

2. Gorbalenya AE et al. Severe acute respiratory syndrome-related coronavirus: The species and its viruses - a statement of the Coronavirus Study Group. Microbiology, 2020.

3. World Health Organization. WHO Coronavirus Disease (COVID-19) Dashboard Available at: $<$ https://covid19.who.int>. Access on: may.2020.

4. Wilson ME, Chen LH. Travelers give wings to novel coronavirus (2019-nCoV). J Travel Med

5. World Health Organization. Coronavirus disease 2019 (COVID-19). Situational Report-37. Disponível em: <https://www.who.int/docs/default-source/coronaviruse/ situation reports/20200226-sitrep-37covid-19.pdf>. Accessed 27 Feb 2020.

6. Acuña-Zegarra MA, Santana-Cibrian M, Velasco-Hernandez JX. Modeling behavioral change and COVID-19 containment in Mexico: A trade-off between lockdown and compliance [published online ahead of print, 2020 May 6]. Math Biosci. 2020;108370. doi:10.1016/j.mbs.2020.108370

7. Jarvis $\mathrm{Cl}$, Van Zandvoort K, Gimma A, et al. Quantifying the impact of physical distance measures on the transmission of COVID-19 in the UK. BMC Med. 2020;18(1):124. Published 2020 May 7. doi:10.1186/s12916-020-01597-8

8. Houghton C, Meskell P, Delaney $\mathrm{H}$, et al. Barriers and facilitators to healthcare workers' adherence with infection prevention and control (IPC) guidelines for respiratory infectious diseases: a rapid qualitative evidence synthesis. Cochrane Database Syst Rev. 2020;4(4):CD013582. Published 2020 Apr 21. doi:10.1002/14651858.CD013582 
9. Hillier MD. Using effective hand hygiene practice to prevent and control infection. Nurs Stand. 2020;35(5):45-50. doi:10.7748/ns.2020.e11552

10. Saitoh A, Sato K, Magara Y, et al. Improving Hand Hygiene Adherence in Healthcare Workers Before Patient Contact: A Multimodal Intervention in Four Tertiary Care Hospitals in Japan. J Hosp Med. 2020;15(5):262-267. doi:10.12788/jhm.3446

11. Ngonghala CN, Iboi E, Eikenberry $\mathrm{S}$, et al. Mathematical assessment of the impact of nonpharmaceutical interventions on curtailing the 2019 novel Coronavirus [published online ahead of print, 2020 May 1]. Math Biosci. 2020;325:108364. doi:10.1016/j.mbs.2020.108364

12. West R, Michie S, Rubin GJ, Amlôt R. Applying principles of behaviour change to reduce SARS-CoV-2 transmission. Nat Hum Behav. 2020;4(5):451-459. doi:10.1038/s41562-020-0887-9

13. Ministério da Saúde. Secretaria de Vigilância em Saúde. Centro de Operações de Emergências em Saúde Pública. Boletim Epidemiológico Especial 14. 2020. Available online: www.saude.gov.br/bvs. Acessed on 30 April 2020.

14. Wang Q, Yu C. The role of masks and respirator protection against SARS-CoV-2. Infect Control Hosp Epidemiol. 2020;41(6):746-747. doi:10.1017/ice.2020.83

15. Noh JY, Seong H, Yoon JG, Song JY, Cheong HJ, Kim WJ. Social Distancing against COVID-19: Implication for the Control of Influenza. J Korean Med Sci. 2020;35(19):e182. Published 2020 May 18. doi:10.3346/jkms.2020.35.e182

16. Zhong BL, Luo W, Li HM, et al. Knowledge, attitudes, and practices towards COVID-19 among Chinese residents during the rapid rise period of the COVID-19 outbreak: a quick online cross-sectional survey. Int J Biol Sci. 2020;16(10):1745-1752. Published 2020 Mar 15. Doi:10.7150/ijbs.45221

17. Hernández-García I, Giménez-Júlvez T. Assessment of Health Information About COVID-19 Prevention on the Internet: Infodemiological Study. JMIR Public Health Surveill. 2020;6(2):e18717. Published 2020 Apr 1. doi:10.2196/18717

18. Geldsetzer P. Use of Rapid Online Surveys to Assess People's Perceptions During Infectious Disease Outbreaks: A Cross-sectional Survey on COVID-19. J Med Internet Res. 2020;22(4):e18790. Published 2020 Apr 2. doi: $10.2196 / 18790$

19. Feng S, Shen C, Xia N, Song W, Fan M, Cowling BJ. Rational use of face masks in the COVID-19 pandemic. Lancet Respir Med. 2020;8(5):434-436. doi:10.1016/S2213-2600(20)30134-X

20. World Health Organization. Available online: https://who.int/news- room/articles-detail/updatedwho-advice-for-international-traffic-in-relation-to-the- outbreak-of-the-novel-coronavirus-2019-ncov-24jan . Accessed on 24 May 2020.

21. Prusaczyk B. Strategies for Disseminating and Implementing COVID-19 Public Health Prevention Practices in Rural Areas [published online ahead of print, 2020 Apr 3]. J Rural Health. 2020;10.1111/jrh.12432. doi:10.1111/jrh.12432

22. Ranscombe P. Rural areas at risk during COVID-19 pandemic. Lancet Infect Dis. 2020;20(5):545. Doi:10.1016/S1473-3099(20)30301-7 
23. Wang P, Lu J-a, Jin Y, Zhu M, Wang L, Chen S, Statistical and network analysis of 1212 COVID-19 patients in Henan, China, International Journal of Infectious Diseases (2020), doi:

24. Kuno Crative. Available online: https://www.kunocreative.com/blog/influencers-doing-good-duringcovid-19. Accessed on 24 May

25. Ministério da Saúde. Secretaria de Vigilância em Saúde. Centro de Operações de Emergências em Saúde Pública. Plano de Contingência Nacional para Infecção Humana pelo novo Coronavírus COVID-19. 1. ed. 2020. Available online: www.saude.gov.br/bvs. Accessed on 24 April 2020.

26. Financial Time analysis of European Centre for Disease Prevention and Control. 2020. Available online: ft.com/coronavirus-latest. Accessed on 30 April 2020.

27. Thomas A Mellan, Henrique H Hoeltgebaum, Swapnil Mishra et al. Estimating COVID-19 cases and reproduction number in Brazil. Imperial College London (08-05- 2020), doi: https://doi.org/10.25561/78872.

28. Giacomelli A et al. 30-day mortality in patients hospitalized with COVID-19 during the first wave of the Italian epidemic: a prospective cohort study. Pharmacol 2020 May 21:104931. doi: 10.1016/j.phrs.2020.104931.

29. Asfahan S. et al. Extrapolation of mortality in COVID-19: Exploring the role of age, sex, co-morbidities and health-care related occupation. Monaldi Arch Chest Dis. 2020 May 21;90(2). doi: 10.4081/monaldi.2020.1325.Monaldi Arch Chest Dis. 2020. PMID: 32447949

30. Valente, J. Covid-19: uso maior da internet requer mais cuidado com segurança. Agência Brasil. 2020. Available online: https://agenciabrasil.ebc.com.br/saude/noticia/2020-03/covid-19-uso-maiorda- internet-requer-mais-cuidado-com-seguranca. Accessed on 30 April

31. COVID-19 in Brazil: "So what?". [editorial]. The Lancet. 2020; 395(10235):1461.

32. Requia WJ et al. Risk of the Brazilian health care system over 5572 municipalities to ex-ceed health care capacity due to the 2019 novel coronavirus (COVID-19) Science of the Total Environment 730 (2020) 139144

33. Comitê Gestor da Internet no Brasil. Núcleo de Informação e Coordenação do Ponto BR. Banda larga no Brasil: um estudo sobre a evolução do acesso e da qualidade das conexões à Internet /[coordenação executiva e editorial Alexandre Barbosa]. São Paulo: Available online: https://cetic.br/media/docs/publicacoes/1/Estudo\%20Banda \%20Larga\%20no\%20Brasil.pdf. Accessed on 24 April 2020.

34. Lima, CKT et al. The emotional impact of Coronavirus 2019-nCoV (new Coronavirus disease). Psychiatry Research 287 (2020)

\section{Figures}




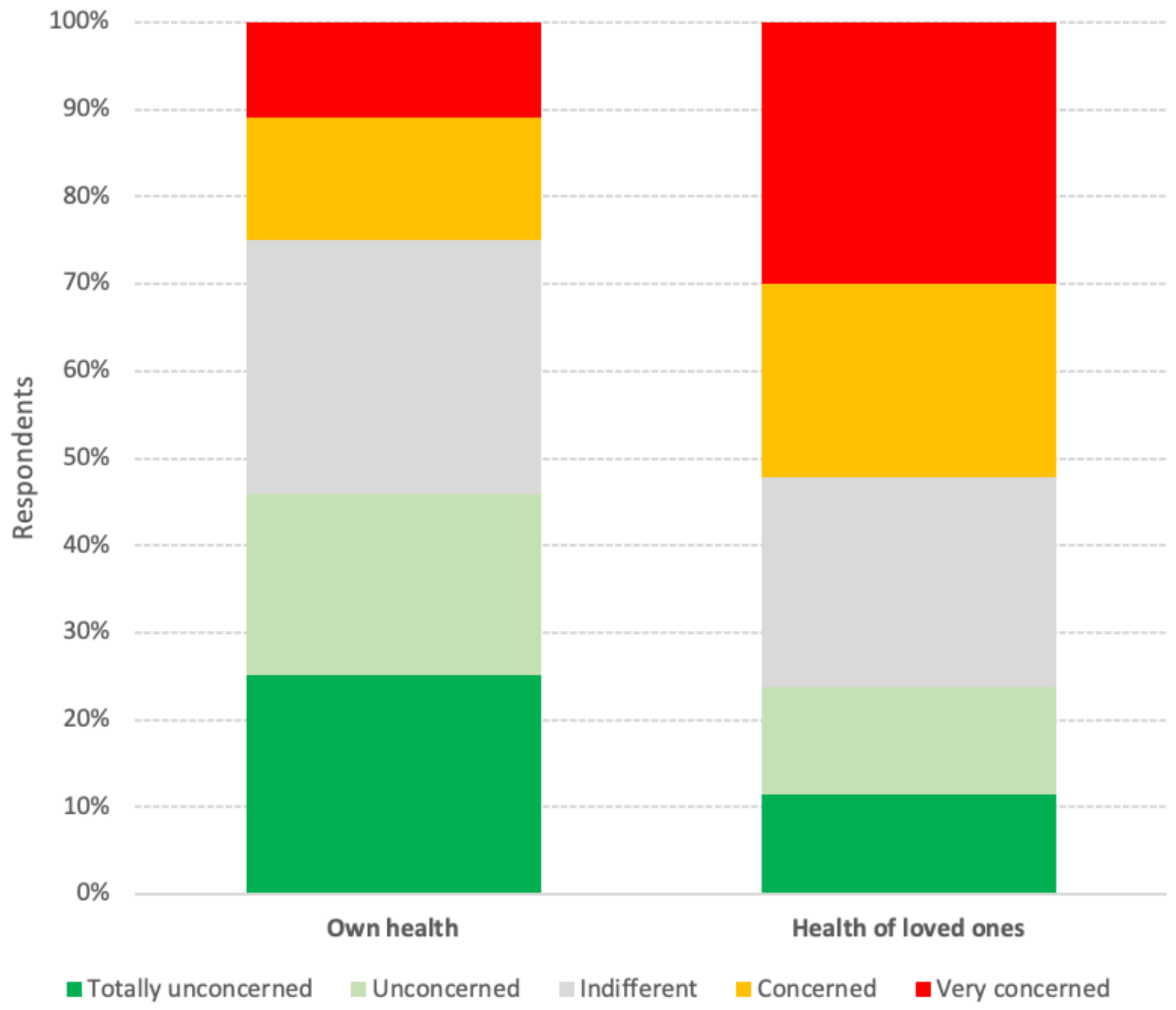

\section{Figure 1}

Level of concern about COVID-19 consequences among participants of an online survey on COVID-19, Brazil, April 2020 (bivariate: self-versus loved ones) 


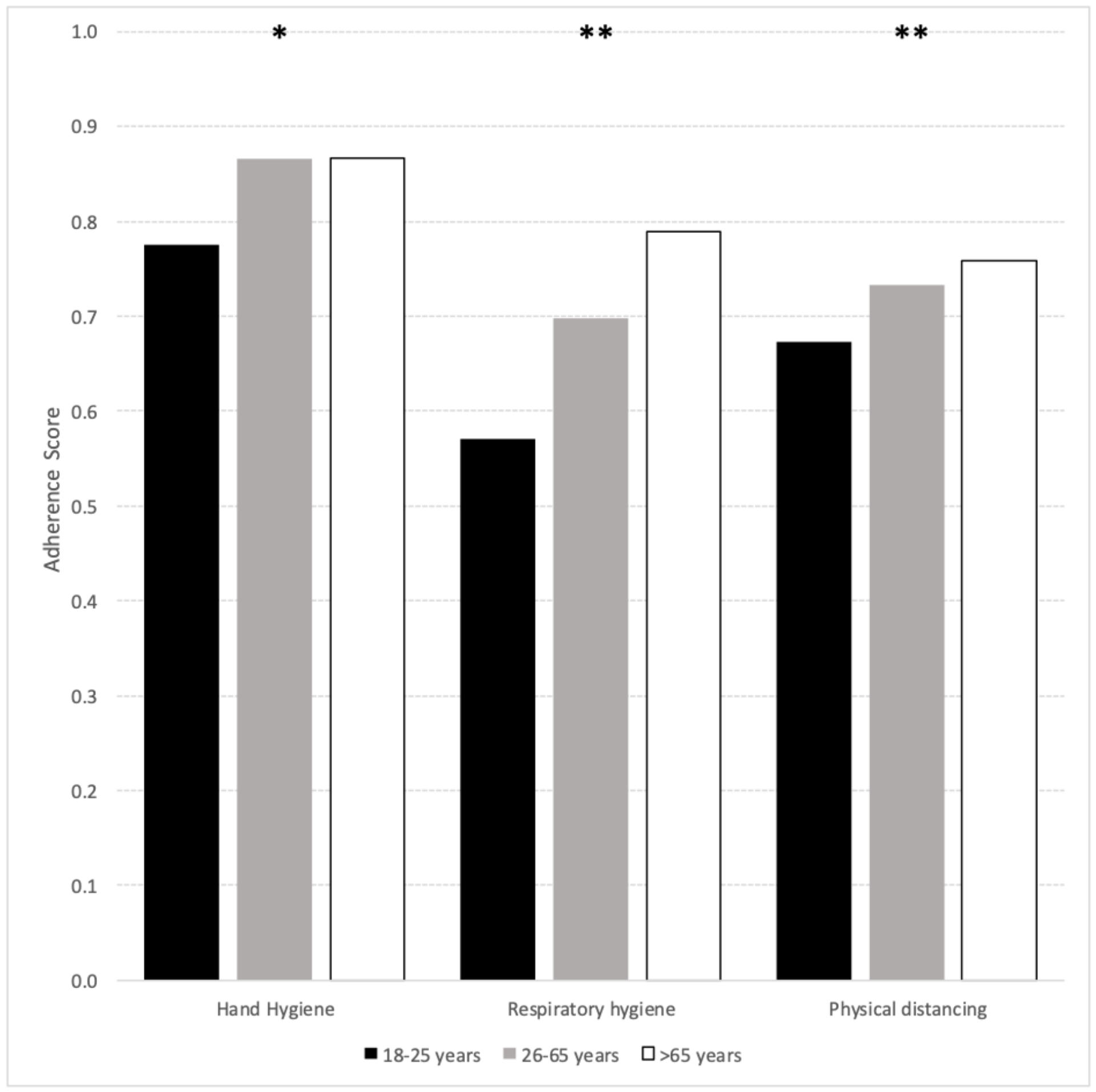

Figure 2

Scores for adherence to COVID-19 containment measures, among respondents of an online survey on COVID-19, per age group, Brazil, April 2020. * $p<0.001$ for $18-25$ years vs $26-65$ years and $>65$ years ** $p<0.001$ for $18-25$ years vs $26-65$ years and $>65$ years; $26-65$ years vs $>65$ years

\section{Supplementary Files}


This is a list of supplementary files associated with this preprint. Click to download.

- Additionalfile1.pdf 